\title{
Foreword to special issue on "Myocarditis"
}

\author{
Alida L. P. Caforio
}

Published online: 2 November 2013

(C) Springer Science+Business Media New York 2013

There are three phases to treatment: diagnosis, diagnosis and diagnosis William Osler W. (1892) Principles and practice of medicine

William Osler, with a very actual sentence, stated, back in year 1892, in its Medicine textbook: "There are three phases to treatment: diagnosis, diagnosis and diagnosis" [1]. This sentence clearly highlights that the best clinical management is based upon the most accurate diagnosis. Historically myocarditis has being considered a rare and poorly understood condition, a conundrum with polymorphic clinical presentation and variable prognosis ranging from spontaneous resolution to progressive heart failure and death. The first comprehensive review with a modern approach to etiopathogenesis was published in 1980 by Woodroof JF, who highlighted the possible etiological role of Coxsackie viruses and of the immune system in the progression of cardiac damage, with possible evolution to a dilated cardiomyopathy [2]. A major advance in diagnosis was the refinement of the endomyocardial biopsy technique using the King's bioptome by Richardson [3]. Another important step was the development of a consensus pathological classification and histological definition of myocarditis by endomyocardial biopsy, known as the Dallas criteria [4]. Meanwhile, the first experimental observations were made by several investigators, suggesting a possible involvement of autoimmune mechanisms to cardiac autoantigens; in particular, a mouse model for myosin-induced autoimmune myocarditis was described by the Neu et al. [5]. In addition, various groups in the late 80 s and early 90 s reported the presence of circulating anti-heart autoantibodies against myosin as well as other

\section{A. L. P. Caforio ( $\square)$}

Division of Cardiology, Department of Cardiological, Thoracic and Vascular Sciences, Centro "V. Gallucci", University of Padova-Policlinico, Via Giustiniani, 2, 35128 Padua, Italy

e-mail: alida.caforio@unipd.it autoantigens in acute and chronic myocarditis or dilated cardiomyopathy, in keeping with the hypothesis of autoimmunity being involved in a subset of patients [6-14]. A retrospective multicenter registry from the USA coordinated by Cooper et al. [15] reported the efficacy of immunosuppressive therapy in a rare but lethal form of myocarditis, e.g., giant cell myocarditis. On these premises, the multicenter Myocarditis Treatment Trial was designed using the Dallas criteria to recruit myocarditis patients to 6 months immunosuppression; the therapy with azathioprine and prednisone or cyclosporine A and prednisone was well tolerated, and no significant effect on survival was observed, although the study was not powered to detect differences in survival [16]. The results of the trial had a profoundly negative effect in the next decade on the use of endomyocardial biopsy to detect and treat myocarditis. However, researchers developed new diagnostic tools to be added to standard histology, in particular immunohistochemistry, to increase sensitivity of endomyocardial biopsy particularly in focal and chronic myocarditis and characterize the number and type of infiltrating inflammatory cells, and molecular detection of genomic material of infectious agents mainly by polymerase chain reaction (PCR), to diagnose infectious, particularly viral myocarditis [17-24]. This work leads to another major step forward, e.g., the 1995 WHO classification of cardiomyopathies, with the acknowledgment that myocarditis is diagnosed on endomyocardial biopsy by established histological, immunological and immunohistochemical criteria; molecular techniques on EMB were recommended to identify viral etiology [25]. In the WHO classification, infectious, autoimmune and idiopathic forms of myocarditis are recognized that may lead to dilated cardiomyopathy [25]. Using serum cardiac autoantibody testing as well as histology, immunohistology and viral PCR on endomyocardial biopsy, it is nowadays possible to define distinct etiopathogenetic 
subsets of myocarditis, in particular infectious versus immune-mediated, e.g., infection-negative forms [26]. This characterization is a key to define who are the infectionnegative cases in which immunosuppression and immunomodulation may be beneficial. Conversely, immunosuppression and immunomodulation are contraindicated in patients with active myocardial infection. In the last years, another fundamental step has been the development of cardiovascular magnetic resonance imaging (CMR) as noninvasive imaging tool in inflammatory heart muscle disease [27, 28]. CMR does not replace endomyocardial biopsy in the diagnosis of myocarditis, it is currently unable to differentiate between infectious and immune-mediated forms, but is a valuable tool to refine the clinical suspicion of myocarditis and for noninvasive follow-up [27-29]. Even more importantly, it is revealing a much more broader prevalence of clinically suspected and unsuspected myocarditis especially in patients with minor symptoms, e.g., young patients with unexplained arrhythmia, or troponin positive patients with normal coronary arteries [28].

In this Special issue, basic and clinical researchers who provided major contributions to the myocarditis field in the last 20 years give an expert overview of some hot issues, from definition and classification to diagnosis and treatment. This work would not have been possible without the serendipity and support of the Editor of Heart Failure Reviews, Dr Sidney Goldstein, who suggested dedicating a special issue to a rare and generally neglected cause of heart failure. The issue is addressed to clinicians as well as basic scientists with an interest in this fascinating disease that most frequently affects young people and is dedicated to our patients, the lucky ones, who underwent cardiac transplantation, and especially those, the unlucky ones, who died because of sudden cardiac death or waiting for a new heart. It is worth noting that many contributors to this Special issue were directly, as authors, or indirectly, as reviewers, members of a European Myocarditis Task Force that produced the first consensus document on myocarditis, that will hopefully facilitate the design of new multicentre trials of etiology-directed treatment in different myocarditis forms, e.g., infectious and immune-mediated, according to the consensus criteria [29]. We are after all following the inspiration of one of the giants in Medicine, William Osler, and hope that his approach will lead to new and effective treatments for our myocarditis patients.

\section{References}

1. Osler W (1892) Principles and practice of medicine. D. Appleton, New York

2. Woodruff JF (1980) Viral myocarditis: a review. Am J Pathol 101:425-484
3. Richardson PJ (1974) King's endomyocardial bioptome. Lancet 1(7859):660-661

4. Aretz HT, Billingham ME, Edwards WE, Factor SM, Fallon JT, Fenoglio JJ Jr, Olsen EG, Schoen FJ (1985) Myocarditis: a histopathologic definition and classification. Am J Cardiol Pathol $1: 1-10$

5. Neu N, Rose NR, Beisel KW, Herskowitz A, Gurri-Glass G, Craig SW (1987) Cardiac myosin induces myocarditis in genetically predisposed mice. J Immunol 139:3630-3636

6. Caforio ALP, Bonifacio E, Stewart JT et al (1990) Novel organspecific circulating cardiac autoantibodies in dilated cardiomyopathy. J Am Coll Cardiol 1990(15):1527-1534

7. Caforio ALP, Goldman JH, Haven AJ, Baig KM, Dalla Libera L, McKenna WJ (1997) Circulating cardiac autoantibodies as markers of autoimmunity in clinical and biopsy-proven myocarditis. Eur Heart J 18:270-275

8. Caforio ALP, Grazzini M, Mann JM, Keeling PJ, Bottazzo GF, McKenna WJ, Schiaffino S (1992) Identification of $\alpha$ - and $\beta$ cardiac myosin heavy chain isoforms as major auto antigens in dilated cardiomyopathy. Circulation 85:1734-1742

9. Lauer B, Schannwell M, Kuhl U, Strauer BE, Schultheiss HP (2000) Antimyosin autoantibodies are associated with deterioration of systolic and diastolic left ventricular function in patients with chronic myocarditis. J Am Coll Cardiol 35:11-18

10. Wallukat G, Morwinski M, Kowal K, Förster A, Boewer V, Wollenberger A (1991) Antibodies against the $\beta$-adrenergic receptor in human myocarditis and dilated cardiomyopathy: $\beta$ adrenergic agonism without desensitization. Eur Heart J 12(Suppl D): $178-181$

11. Schultheiss HP, Ulrich G, Janda I, Melzner B, Ulrich G, Morad M (1988) Antibody mediated enhancement of calcium permeability in cardiac myocytes. J Exp Med 168:2105-2119

12. Klein R, Maisch B, Kochsiek K, Berg PA (1984) Demonstration of organ specific antibodies against heart mitochondria (anti-M7) in sera from patients with some forms of heart diseases. Clin Exp Immunol 58:283-292

13. Ansari AA, Neckelmann N, Villinger F, Leung P, Danner DJ, Brar SS, Zhao S, Gravanis MB, Mayne A, Gershwin ME, Herskowitz A (1994) Epitope mapping of the branched chain $\alpha$ ketoacid dehydrogenase dihydrolipoyl transacylase (BCKD-E2) protein that reacts with sera from patients with idiopathic dilated cardiomyopathy. J Immunol 153:4754-4765

14. Fu LX, Magnusson Y, Bergh CH, Liljeqvist JA, Waagstein F, Hjalmarson A, Hoebeke J (1993) Localization of a functional autoimmune epitope on the muscarinic acetylcholine receptor-2 in patients with idiopathic dilated cardiomyopathy. J Clin Invest 91:1964-1968

15. Cooper LT, Berry GJ, Shabetai R (1997) Idiopathic giant-cell myocarditis-natural history and treatment. Multicenter giant cell myocarditis study group investigators. $N$ Engl J Med 336: 1860-1866

16. Mason JW, O'Connell JB, Herskowitz A, Rose NR, McManus BM, Billingham ME, Moon TE, The Myocarditis Treatment Trial Investigators (1995) A clinical trial of immunosuppressive therapy for myocarditis. N Engl J Med 333:269-275

17. Schnitt SJ, Ciano PS, Schoen FJ (1987) Quantitation of lymphocytes in endomyocardial biopsies: use and limitations of antibodies to leukocyte common antigen. Hum Pathol 18: 796-800

18. Kuhl U, Noutsias M, Seeber B, Schultheiss HP (1996) Immunohistological evidence for a chronic intramyocardial inflammatory process in dilated cardiomyopathy. Heart 75:295-300

19. Herskowitz A, Ahmed-Ansari A, Neumann DA, Beschorner WE, Rose NR, Soule LM, Burek CL, Sell KW, Baughman KL (1990) Induction of major histocompatibility complex antigens within 
the myocardium of patients with active myocarditis: a nonhistologic marker of myocarditis. J Am Coll Cardiol 15:624-632

20. Bowles NE, Richardson PJ, Olsen EG, Archard LC (1986) Detection of Coxsackie-B-virus-specific RNA sequences in myocardial biopsy samples from patients with myocarditis and dilated cardiomyopathy. Lancet 1:1120-1123

21. Chapman NM, Tracy S, Gauntt CJ, Fortmueller U (1990) Molecular detection and identification of enteroviruses using enzymatic amplification and nucleic acid hybridization. J Clin Microbiol 28:843-850

22. Hilton DA, Variend S, Pringle JH (1993) Demonstration of Coxsackie virus RNA in formalin-fixed tissue sections from childhood myocarditis cases by in situ hybridization and the polymerase chain reaction. J Pathol 170:45-51

23. Martin AB, Webber S, Fricker FJ, Jaffe R, Demmler G, Kearney D, Zhang YH, Bodurtha J, Gelb B, Ni J (1994) Acute myocarditis. Rapid diagnosis by PCR in children. Circulation 90: 330-339

24. Pauschinger M, Bowles NE, Fuentes-Garcia FJ, Pham V, Kühl U, Schwimmbeck PL, Schultheiss HP, Towbin JA (1999) Detection of adenoviral genome in the myocardium of adult patients with idiopathic left ventricular dysfunction. Circulation 99:1348-1354

25. Richardson P, McKenna WJ, Bristow M, Maisch B, Mautner B, O'Connell J, Olsen E, Thiene G, Goodwin J, Gyarfas I, Martin I, Nordet P (1996) Report of the 1995 WHO/ISFC task force on the definition of cardiomyopathies. Circulation 93:841-842
26. Caforio AL, Calabrese F, Angelini A, Tona F, Vinci A, Bottaro S, Ramondo A, Carturan E, Iliceto S, Thiene G, Daliento L (2007) A prospective study of biopsy-proven myocarditis: prognostic relevance of clinical and aetiopathogenetic features at diagnosis. Eur Heart J 28:1326-1333

27. Friedrich MG, Sechtem U, Schulz-Menger J, Holmvang G, Alakija P, Cooper LT, White JA, Abdel-Aty H, Gutberlet M, Prasad S, Aletras A, Laissy JP, Paterson I, Filipchuk NG, Kumar A, Pauschinger M, Liu P, International Consensus Group on Cardiovascular Magnetic Resonance in Myocarditis (2009) Cardiovascular magnetic resonance in myocarditis: a JACC white paper. J Am Coll Cardiol 53:1475-1487

28. Baccouche H, Mahrholdt H, Meinhardt G, Merher R, Voehringer M, Hill S, Klingel K, Kandolf R, Sechtem U, Yilmaz A (2009) Diagnostic synergy of non-invasive cardiovascular magnetic resonance and invasive endomyocardial biopsy in troponin-positive patients without coronary artery disease. Eur Heart J 30:2869-2879

29. Caforio ALP, Pankuweit S, Arbustini E, Basso C, Gimeno-Blanes J, Felix SB, Fu M, Heliö T, Heymans S, Jahns R, Klingel K, Linhart A, Maisch B, McKenna WJ, Mogensen J, Pinto Y, Ristic A, Schultheiss HP, Hubert Seggewiss H, Tavazzi L, Thiene G, Yilmaz A, Charron P, Elliott PM (2013) Current state of knowledge on aetiology, diagnosis, management and therapy of myocarditis. A position statement of the European Society of Cardiology working group on myocardial and pericardial diseases. Eur Heart J 34:2636-2648 